\title{
Eksplorasi Geokimia untuk Menentukan Daerah Prospek Mineralisasi Emas Tipe Urat Epitermal: Studi Kasus di Daerah Tompaso, Kabupaten Minahasa Selatan, Sulawesi Utara
}

\section{Geochemical Exploration to Determine the Prospect Area of Epithermal Vein- Type Gold Mineralization: A Case Study in Tompaso Region, South Minahasa District, North Sulawesi}

\author{
Arifudin Idrus $^{1 *}$, Fadlin $^{2}$, Hill Gendoet Hartono ${ }^{3}$ \\ ${ }^{1}$ Departemen Teknik Geologi, Universitas Gadjah Mada \\ Jl. Jl. Grafika Bulaksumur No.2, Sleman, Daerah Istimewa Yogyakarta, Indonesia, 55284 \\ ${ }^{2}$ Program Studi Teknik Geologi, Universitas Jenderal Soedirman \\ Jl. Mayjen Sungkono Km. 5, Purbalingga, Jawa Tengah, Indonesia, 53371 \\ ${ }^{3}$ Program Studi Teknik Geologi, Institut Teknologi Nasional \\ Jl. Babarsari, Tambak Bayan, Depok, Sleman, Daerah Istimewa Yogyakarta, Indonesia, 55281 \\ *E-mail: arifidrus@ugm.ac.id
}

Naskah diterima: 4 Februari 2021, direvisi: 13 April 2021, disetujui: 22 April 2021

DOI: 10.17146/eksplorium.2021.42.1.6230

\begin{abstract}
ABSTRAK
Sulawesi Utara termasuk daerah Tompaso, Kabupaten Minahasa Selatan merupakan jalur magmatik yang potensial menghasilkan endapan bijih hidrotermal. Penelitian ini bertujuan menentukan daerah prospek mineralisasi emas khususnya tipe urat epitermal berdasarkan eksplorasi geokimia meliputi geokimia batuan dan sedimen sungai, khususnya metode BLEG (Bulk Leach Extractable Gold). Metode penelitian meliputi pemetaan geologi, alterasi dan jalur urat, percontoan (bijih/batuan dan sedimen sungai), dan analisis geokimia. Sampel bijih dianalisis dengan metode FA/AAS untuk emas dan metode AAS untuk unsur lain, sedangkan analisis sampel sedimen sungai dilakukan dengan metode cyanide leach dan AAS. Hasil penelitian menunjukkan batuan induk mineralisasi berupa lava andesit dan intrusi diorit. Batuan ini mengalami alterasi silica-clay, argilik, dan propilitik. Perpaduan antara pemetaan geologi, zona alterasi, dan jalur urat dengan eksplorasi-geokimia batuan dapat menentukan daerah prospek mineralisasi yaitu Prospek Asam dan Polangkok. Pada Prospek Asam, sampel bijih memiliki kandungan emas sampai 0,03 ppm dengan anomali emas pada sampel BLEG menunjukkan nilai threshold 13,52 ppb Au. Pada Prospek Polangkok ditemukan 2 jalur urat (P1 dan P2) berarah baratlaut-tenggara dengan lebar sampai $5 \mathrm{~m}$. Urat P1 memiliki kadar Au mencapai 0,31 ppm dan pada urat P2 mencapai 0,16 ppm Au. Mineralisasi pada Prospek Polangkok didukung oleh anomali Ag pada sampel BLEG dengan nilai threshold 67,18 ppb. Kedua daerah prospek tersebut direkomendasikan untuk eksplorasi lanjut (follow-up exploration).
\end{abstract}

Kata kunci: Tompaso, geokimia, BLEG, urat epitermal, daerah prospek.

\begin{abstract}
North Sulawesi, including the Tompaso region, South Minahasa district, is a part of the magmatic belts hosting potential hydrothermal ore deposits. This study is aimed to determine the prospect area for epithermal vein-type gold mineralization, based on geochemical exploration including rock and BLEG (Bulk Leach Extractable Gold) stream sediment geochemistry. Mapping of geology, alteration and vein direction, sampling (ore/rock and stream sediment), and geochemical analysis were performed. Gold in rock samples was analyzed by FA/AAS, and other elements were detected by AAS, while BLEG samples were analyzed using the cyanide leach and AAS methods. The study area is occupied by andesitic lava and diorite, which are suffered by silica-clay, argillic and propylitic alteration. An integration of geological mapping, alteration zones and vein direction with lithogeochemical survey enables to determine the prospect areas, which consist of Asam and Polangkok prospects. At the Asam prospect, the ore sample contains gold up to 0.03 ppm, where the gold anomaly in BLEG samples show a threshold of 13.52
\end{abstract}


ppb Au. At the Polangkok prospect, two NW-SE trending veins (P1 and P2 Veins) were discovered with a width of up to $5 \mathrm{~m}$. Vein P1 and P2 contains of up to 0.31 and $0.16 \mathrm{ppm} A u$, respectively. Mineralization at the Polangkok prospect coincides with Ag anomaly of BLEG samples with a threshold of $67.18 \mathrm{ppb}$. The two prospect areas are recommended for follow-up exploration.

Keywords: Tompaso, Geochemistry, BLEG, vein-type epithermal, prospect area.

\section{PENDAHULUAN}

Indonesia memiliki tataan tektonik yang mendukung dan favorable terbentuknya endapan-endapan emas tipe hidrotermal yang potensial [1-3]. Salah satu daerah potensial tersebut adalah lengan utara Pulau Sulawesi [4], [5], khususnya di Kabupaten Minahasa Selatan, Provinsi Sulawesi Utara. Sebagai bagian dari busur magmatik Sulawesi Utara, Kabupaten Minahasa Selatan memiliki lingkungan magmatik yang memungkinkan untuk terbentuk mineralisasi emas dan bijih lainnya dengan tipe endapan yang bervariasi, seperti endapan porfiri, epitermal, VMS, dan sediment-hosted [1], [4-7]. Berdasarkan hasil eksplorasi berbagai pihak, daerah Minahasa memiliki keunikan pada tipe endapan yang dijumpai, antara lain endapan emas epitermal bertipe urat pada batuan induk (host rock) berupa batuan vulkanik [8] dan endapan emas hasil proses penggantian (replacement) pada batuan induk berupa batuan sedimen karbonat [9], [10].

Sehubungan dengan melonjaknya kebutuhan emas disertai dengan naiknya harga emas di pasaran dunia secara terus menerus [11], [12], maka diperlukan kegiatan eksplorasi emas yang berkesinambungan. Tulisan ini membahas tentang kegiatan eksplorasi geokimia pada wilayah IUP Eksplorasi di daerah Tompaso, Kabupaten Minahasa Selatan, Provinsi Sulawesi Utara (Gambar 1). Tulisan ini bertujuan untuk menjelaskan metode eksplorasi geokimia yang terdiri dari geokimia batuan dan sedimen sungai, khususnya metode BLEG (Bulk Leach
Extractable Gold), untuk menentukan daerah prospek mineralisasi emas tipe urat epitermal pada daerah penelitian. Metode eksplorasi ini dipadukan dengan metode pemetaan geologi, pemetaan mineralisasi (urat), dan zona alterasi hidrotermal.

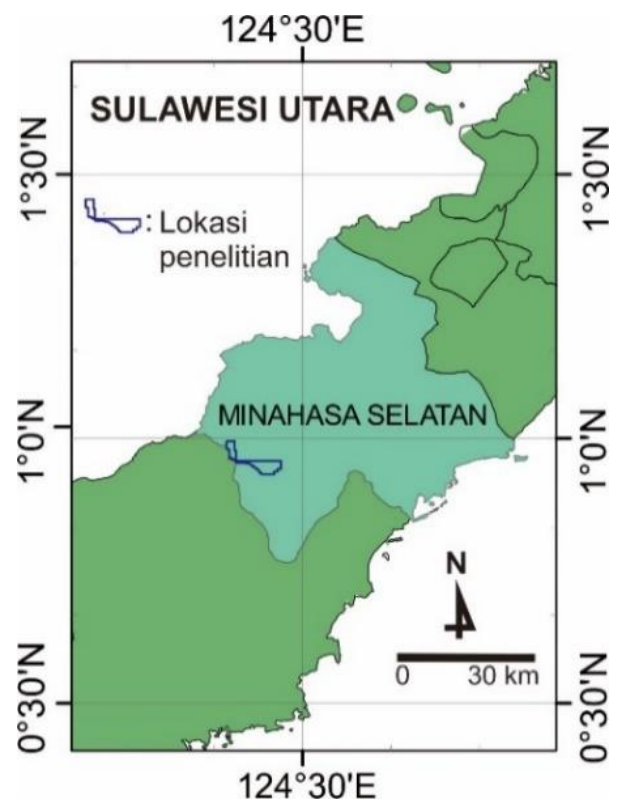

Gambar 1 Peta lokasi penelitian terletak di daerah Tompaso, Kabupaten Minahasa Selatan, Provinsi Sulawesi Utara.

\section{GEOLOGI REGIONAL}

Sulawesi merupakan pulau berbentuk "K" yang memiliki tataan tektonik dan magmatisme yang kompleks. Pulau ini terletak pada pertemuan 3 mega-lempeng yaitu Eurasia, Indo-Australia dan Pasifik, dimana subduksi (subduction) dan kolisi (collision) pernah dan masih aktif terjadi [13-16]. Kompleksitas tektonik dan magmatisme tercermin pada struktur geologi dan batuan penyusun pulau tersebut [16]. Berdasarkan himpunan batuan penyusunnya, Sulawesi 
dapat dibagi dalam 3 provinsi geologi utama yaitu, (1) Sulawesi Barat yang utamanya tersusun oleh batuan sedimen dan vulkanik Tersier, (2) Sulawesi Tengah dan Tenggara yang didominasi batuan metamorf, dan (3) Sulawesi Timur yang tersusun oleh ofiolit menumpang di atas batuan sedimen MesozoikPaleozoik [17]. Kumpulan batuan dari busur kepulauan, batuan bancuh, ofiolit, dan bongkah dari mikrokontinen terbawa bersama proses penunjaman, tubrukan, serta proses tektonik lainnya [18]. Keberadaan sejumlah endapan emas epitermal maupun porfiri di Pulau Sulawesi sangat berkaitan dengan tataan tektonik tersebut.

Daerah penelitian termasuk dalam wilayah Provinsi Sulawesi Utara yang merupakan bagian dari Lengan Utara Pulau Sulawesi. Bagian ini merupakan jalur magmatik bagian timur dari Paparan Sunda. Sekuen batuan yang menyusun bagian utara Pulau Sulawesi dapat dibagi menjadi tiga kelompok yang dipisahkan oleh ketidakselarasan regional, yaitu kelompok batuan Kenozoik Awal, Kenozoik Tengah, dan Kenozoik Akhir [7], [19]. Berdasarkan pembagian tersebut, daerah Minahasa termasuk dalam kelompok Kenozoik Akhir [7] (Gambar 2).

Secara regional, daerah Minahasa didominasi oleh tiga kelompok struktur geologi, yaitu kelompok sesar mendatar dan kelurusan yang panjang dengan arah E-SE yang merupakan struktur yang bersifat paralel, kelompok zona sesar normal yang berarah NW-NNW, serta sesar normal konjungsi yang berarah NE-ENE dengan dimensi yang relatif pendek. Mineralisasi banyak dijumpai pada zona sesar yang berarah NW. Berdasarkan Peta Geologi Regional Lembar Kotamobagu [20], daerah penelitian didominasi oleh kelurusan berarah relatif timur laut-barat daya (NE-SW).

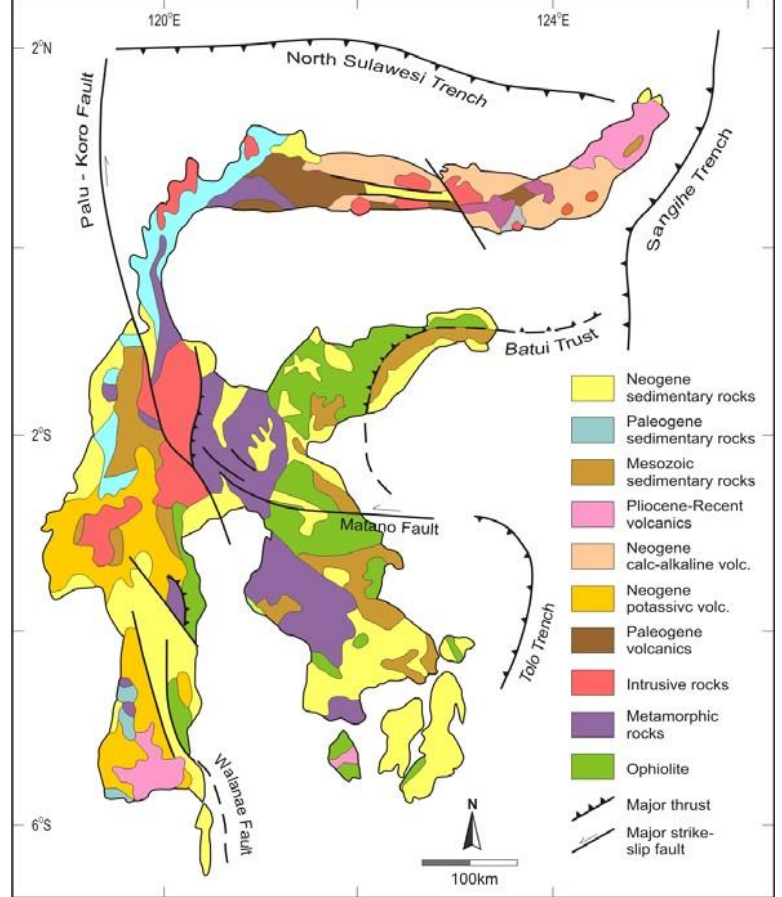

Gambar 2. Peta geologi regional pulau Sulawesi [7].

Daerah lengan utara Pulau Sulawesi memiliki sumberdaya mineral yang melimpah. Pada daerah Minahasa dan Gorontalo, terdapat sejumlah daerah prospek endapan mineral logam yang bernilai ekonomis. Secara umum daerah Minahasa tertutup oleh endapan vulkanik Pliosen secara luas. Pada daerah ini fase mineralisasi yang dianggap paling produktif adalah periode akhir Kenozoikum yang disertai intensitas vulkanisme yang sangat intensif dan meluas. Unit vulkanik pada daerah Minahasa yang secara umum berasosiasi dengan mineralisasi adalah Breksi Toka Tindung dan Tufa Tondano yang berumur Pliosen Akhir [20]. Pada daerah Minahasa dan sekitarnya terdapat beberapa tipe endapan emas seperti epitermal sulfidasi tinggi (Bakan), epitermal sulfidasi rendah (Toka Tindung), epitermal sulfidasi menengah (Doup, Lanut, dan Benteng), sediment hosted atau Carlin-type (Mesel), serta sejumlah endapan mineral logam bernilai ekonomis lainnya [7], [19]. 


\section{METODOLOGI}

Metode penelitian (eksplorasi) yang diterapkan terdiri dari pemetaan geologi permukaan dan zona alterasi-mineralisasi wilayah prospek dengan skala 1:25.000, pengambilan sampel batuan teralterasi dan termineralisasi, serta pengambilan sampel sedimen sungai dengan metode Bulk Leach Extractable Gold (BLEG) yang mewakili daerah catchment tertentu [21-25]. Sampel terpilih dianalisis di laboratorium geokimia. Kegiatan pemetaan di lapangan dilakukan melalui pengamatan singkapan yang dijumpai pada tebing-tebing maupun sepanjang alur sungai. Pengamatan secara detail dilakukan pada setiap singkapan, meliputi pengamatan jenis litologi, struktur geologi, dimensi singkapan, serta kehadiran alterasi maupun mineralisasi. Pada setiap lokasi pengamatan juga dilakukan pengeplotan pada GPS, pengambilan foto, serta pengambilan sampel batuan. Pengambilan sampel dilakukan pada setiap singkapan batuan yang dianggap memiliki indikasi kehadiran alterasi maupun mineralisasi secara sistematis dengan jumlah sampel yang representatif.

\section{Teknik Pengambilan Sampel}

Pengambilan sampel batuan pada daerah penelitian dilakukan secara manual dengan menggunakan peralatan standar dengan bobot rata-rata sampel sekitar $2 \mathrm{~kg}$. Analisis geokimia di laboratorium dilakukan untuk memastikan adanya kandungan unsur emas, perak, maupun unsur logam berharga lainnya. Analisis geokimia dilakukan pada 29 sampel batuan. Sampel batuan tersebut terdiri dari dua jenis, yaitu:

a) Rock Float Sample (RF) yang merupakan sampel batuan termineralisasi yang diambil pada alur sungai. b) Rock Sample (RS) merupakan sampel batuan termineralisasi yang diambil langsung pada batuan yang dianggap memiliki indikasi mineralisasi menarik.

\section{Prosedur BLEG Sampling}

Metode ini dikembangkan pada awal tahun 1980 untuk analisis endapan emas berbutir halus dan sampel yang beragam. Pengambilan sampel BLEG lebih efisien karena dapat mewakili suatu daerah yang luas, murah, cepat, dan memiliki tingkat akurasi lebih tinggi [26-28]. Pengambilan sampel pada metode BLEG harus memperhatikan quality control dengan bobot kering sampel adalah sekitar 2-5 $\mathrm{kg}$ dan proses pengambilan sampel tidak memakai bahan logam. Pengambilan sampel sedimen yang berbutir halus di sepanjang sungai aktif dapat dilakukan di tepi sungai, di bawah batuan yang telah mengalami transportasi, dan di tengahtengah sungai. Dalam hal ini, hal yang harus diperhatikan yaitu tidak boleh mengambil sampel di dekat singkapan dan bekas longsoran dari bukit. Sasaran metode ini adalah floating gold, yaitu fraksi emas yang mengambang dan tertransportasi dari hulu.

Penggumpalan lumpur dengan magnafloc akan menghasilkan air yang sudah terpisah, kemudian dibuang hingga hanya menyisakan lumpur yang sudah menggumpal. Fraksi lempung/lumpur tersebut disaring dengan kantong sampel dari kain agar air terpisah dan menyisakan hanya hanya material fraksi lempung/lumpur. Sampel tersebut merupakan sampel BLEG yang siap dianalisis di laboratorium. Total jumlah sampel BLEG yang diambil pada daerah penelitian adalah 16 sampel. Lokasi pengambilan sampel baik batuan maupun sedimen sungai (BLEG) dapat dilihat pada Gambar 3. 


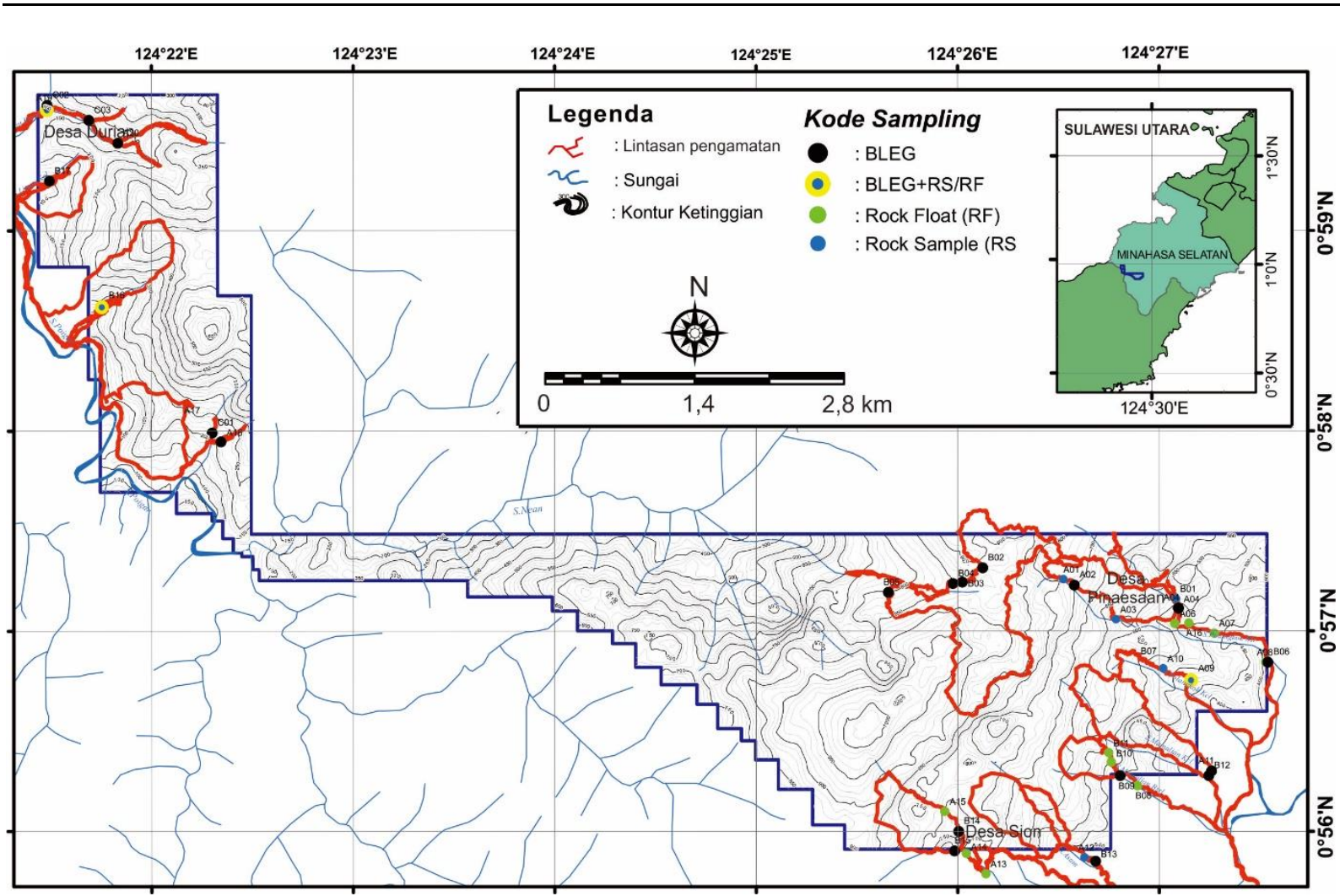

Gambar 3. Peta lokasi pengambilan sampel batuan dan sedimen sungai (BLEG).

\section{Analisis Kimia Batuan dan Sedimen Sungai (BLEG)}

Sebelum dilakukan analisis laboratorium, semua sampel disortir ulang untuk menentukan sampel yang layak dan perlu dilakukan analisis lebih lanjut serta jenis analisis yang perlu dilakukan. Analisis unsurunsur kimia di laboratorium dilakukan untuk mengetahui kadar unsur terpilih, dalam hal ini $\mathrm{Au}, \mathrm{Ag}, \mathrm{Pb}, \mathrm{Zn}$, dan As, pada beberapa sampel batuan batuan dan sedimen sungai (BLEG) terpilih dari lokasi penelitian.

Analisis laboratorium dilakukan di Laboratorium Geokimia Intertek di Jakarta. Sampel batuan dan sampel sedimen sungai (BLEG) dianalisis dengan metode yang berbeda.

a. Sampel batuan

Unsur Emas $(\mathrm{Au})$ pada sampel batuan dianalisis dengan menggunakan metode fire assay (FA) dengan kode FA50, sedangkan unsur lainnya seperti $\mathrm{Ag}, \mathrm{Cu}$, $\mathrm{Pb}, \mathrm{Zn}$ dan As dianalisis dengan menggunakan metode AAS yang sebelumnya dicuci terlebih dahulu dengan dua jenis asam yaitu asam perchloric dan asam hidrochloric.

b. Sampel sedimen sungai (BLEG)

Unsur yang dianalisis pada sampel sedimen sungai adalah $\mathrm{Au}$ dan Ag. Kedua unsur tersebut dianalisis dengan menggunakan metode cyanide leach pada derajat rendah (kode analisis $\mathrm{CNO}_{2}$ ) dan AAS. Metode ini khusus digunakan untuk sampel BLEG yang memiliki bobot kurang dari $5 \mathrm{~kg}$.

\section{Intergrasi dan Analisis Data}

Semua data yang diperoleh berupa data hasil penelitian terdahulu, data hasil pemetaan, geokimia batuan, serta geokimia sedimen sungai (BLEG) dikompilasi untuk memperoleh hasil penelitian secara keseluruhan. Hasil akhir laporan ini adalah data geologi, data alterasi dan mineralisasi, 
serta rekomendasi daerah target untuk Nilai background=Mean

kegiatan eksplorasi selanjutnya.

Analisis dan interpretasi data geokimia

Nilai threshold $=$ Mean $+(2 \times$ Standar Deviasi $)$ hasil analisis laboratorium batuan dan sedimen sungai akan dipisahkan untuk memudahkan pengolahan data. Nilai background atau nilai rata-rata kadar unsur $\mathrm{Au}$ dan $\mathrm{Ag}$ di daerah penelitian adalah sama dengan nilai mean atau median. Sedangkan nilai ambang batas (threshold, istilah yang dipakai pada tulisan ini) atau nilai anomali kadar yang dapat dianggap signifikan dihitung dengan menjumlahkan mean atau median dengan dua kali standar deviasi [22]. Adapun rumus untuk perhitungan nilai background dan threshold

\section{HASIL DAN PEMBAHASAN Geologi Daerah Penelitian}

Daerah penelitian tersusun oleh tiga satuan litologi, berurut dari yang tertua sampai yang paling muda, yaitu satuan lava andesit, satuan breksi andesit, dan satuan diorit (Gambar 4). Satuan lava andesit dan breksi andesit merupakan bagian dari Batuan Gunungapi Bilungala, sedangkan satuan diorit merupakan bagian dari Intrusi Diorit Bone [20]. [22], [23], [25] adalah:

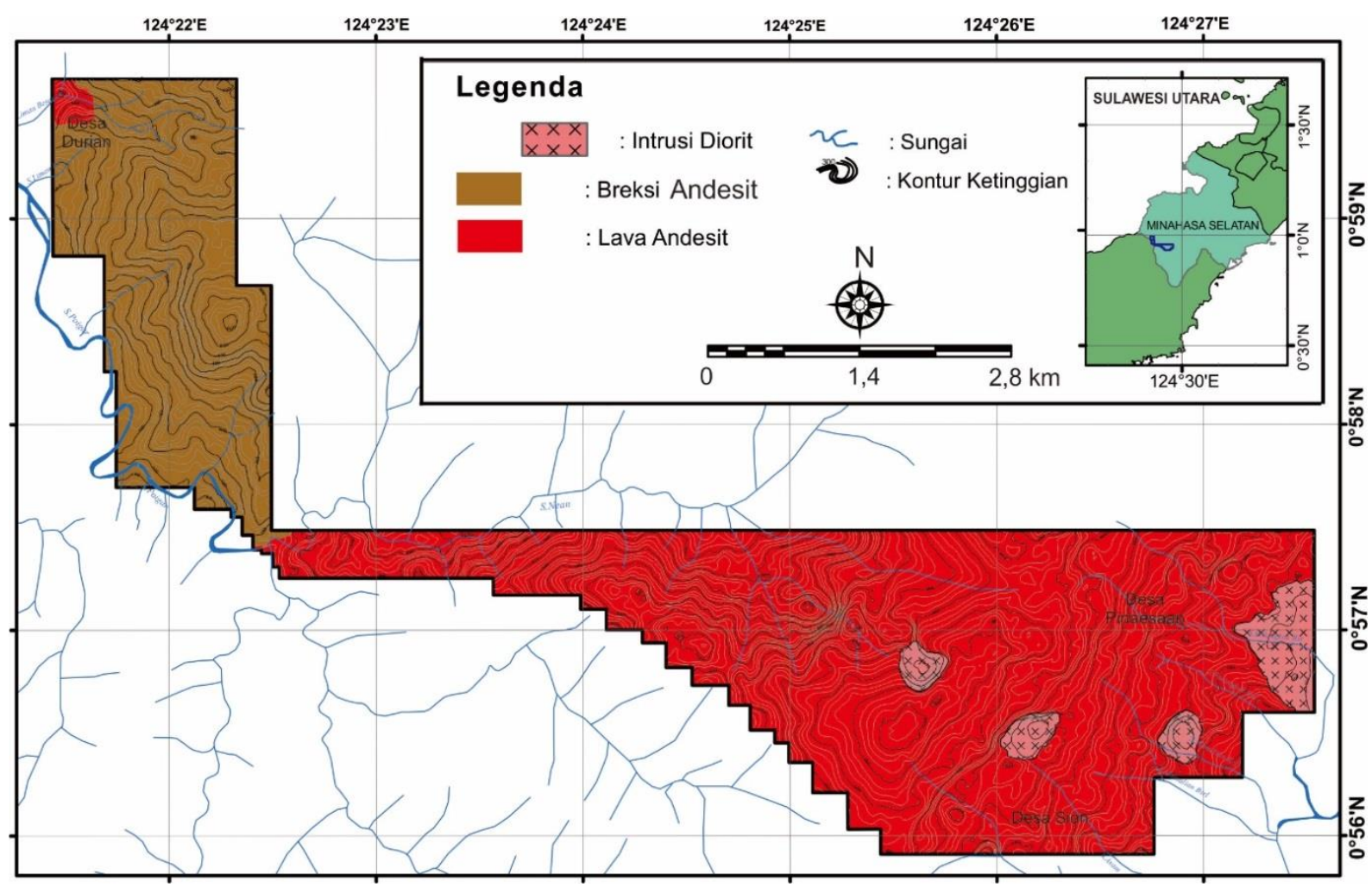

Gambar 4. Peta geologi daerah Tompaso, Kabupaten Minahasa Selatan.

\section{Satuan Lava Andesit}

Andesit berwarna abu-abu gelap cenderung ke arah basaltik, tekstur afanitik, dan sebagian telah mengalami alterasi berupa propilitik dengan derajat rendah sampai menengah. Namun, pada beberapa tempat dijumpai derajat alterasi propilitik yang tinggi terutama pada daerah yang memiliki tingkat rekahan yang intensif dan pada lokasi yang berdekatan dengan intrusi diorit. Andesit 
teralterasi propilitik memiliki ciri berwarna hijau keabu-abuan dan tersusun oleh klorit yang melimpah. Pada beberapa tempat dijumpai andesit teralterasi propilitik yang membentuk kenampakan semacam urat dengan arah relatif timur laut-barat daya. Umumnya dimensi andesit teralterasi propilitik yang membentuk kenampakan semacam urat tersebut tidak terlalu lebar, yaitu sekitar 0,2-1,3 meter.

\section{Satuan Breksi Andesit}

Breksi andesit memiliki pelamparan yang cukup luas yaitu pada sepanjang aliran sungai Poigar. Secara megaskopis breksi andesit memiliki ciri-ciri berwarna abu-abu kecoklatan, tersusun oleh fragmen berupa andesit dan basalt berukuran kerikil-kerakal, dan matrik berupa material vulkanik berukuran sedang sampai halus. Pada beberapa tempat, breksi menunjukkan kenampakan autoklastik dengan fragmen dan matrik tersusun oleh andesit. Pada satuan ini tidak dijumpai mineralisasi yang menarik.

\section{Satuan Diorit}

Intrusi diorit dijumpai di sekitar Sungai Polangkok Kecil di daerah Tompaso. Pada daerah tersebut umumnya intrusi diorit jarang dijumpai sebagai singkapan, sebagian besar dijumpai sebagai bongkah-bongkah yang berukuran besar pada daerah lereng maupun puncak bukit. Diorit memiliki ciri umum di lapangan berwarna abu-abu, tekstur porfiritik, memiliki komposisi mineral primer berupa plagioklas sebagai fenokris, biotit, piroksen dan mineral sekunder berupa kuarsa, serisit, dan klorit. Retas-retas diorit tidak berdimensi besar, umumnya berkisar antara 0,5-1 meter. Tidak dijumpai adanya mineralisasi pada diorit di daerah Polangkok Kecil, namun pada diorit yang dijumpai di bagian timur daerah penelitian, yaitu di sekitar lereng barat Gunung
Payung, terdapat mineralisasi dengan derajat rendah yang ditunjukkan dengan kehadiran pirit yang tersebar (disseminated) pada diorit yang telah terubah. Diorit pada daerah penelitian umumnya mengalami alterasi propilitik berderajat rendah serta masih memperlihatkan tekstur asli batuan. Pada bagian timur dari daerah penelitian dijumpai tubuh intrusi diorit yang cukup besar dengan kondisi sebagian singkapan sudah mengalami perubahan menjadi mineral lempung.

\section{Alterasi Hidrotermal}

Indikasi alterasi dijumpai pada beberapa lokasi di aliran Sungai Polangkok Besar dan Polangkok Kecil. Tipe alterasi yang dijumpai berupa silica-clay, sedikit argilik, serta alterasi propilitik yang cukup luas. Adapun rincian tipe alterasi hidrotermal di daerah penelitian adalah sebagai berikut:

\section{Alterasi silica-clay}

Zona alterasi ini menempati sebagian kecil daerah penelitian yang dicirikan oleh penggantian mineral-mineral utama dan pengayaan kuarsa akibat proses hidrotermal. Zona alterasi ini merupakan zona urat yang memotong satuan andesit. Urat menunjukkan kehadiran silika yang tinggi namun terlihat juga kehadiran mineral lempung yang cukup intensif sehingga penamaan lapangannya adalah silica-clay (Gambar 5). Pada daerah penelitian dijumpai dua urat yaitu pada cabang kiri dan cabang kanan Sungai Polangkok Besar.

Ciri dari zona alterasi ini di lapangan adalah warna putih keabu-abuan, tersusun atas kuarsa dan mineral lempung, dan menunjukkan tingkat mineralisasi cukup tinggi berupa pirit dan mineral sulfida yang terdapat sebagai jalur-jalur sulfida berukuran halus. 


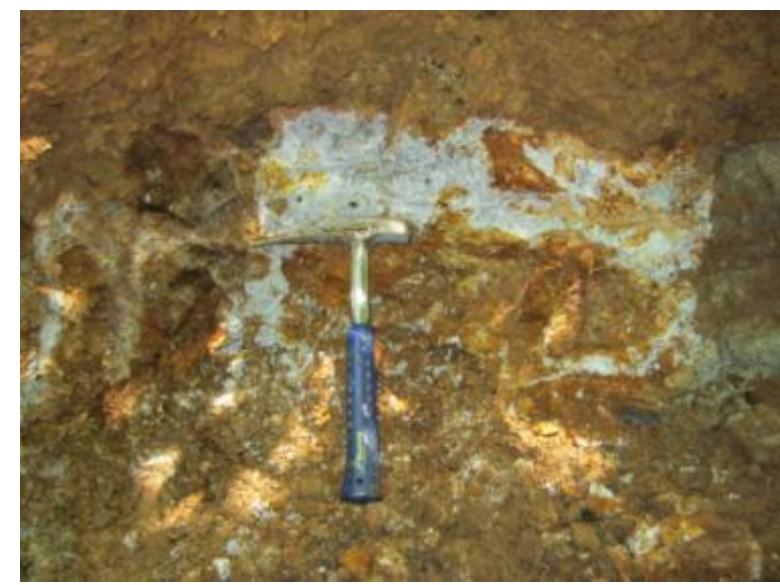

Gambar 5. Singkapan alterasi silica-clay pada alur Sungai Polangkok Besar.

\section{Alterasi argilik}

Tipe alterasi ini tidak berkembang secara meluas pada daerah penelitian. Kehadiran alterasi argilik dikenali dengan kelimpahan mineral lempung yang merupakan ubahan mineral primer seperti feldspar (Gambar 6).

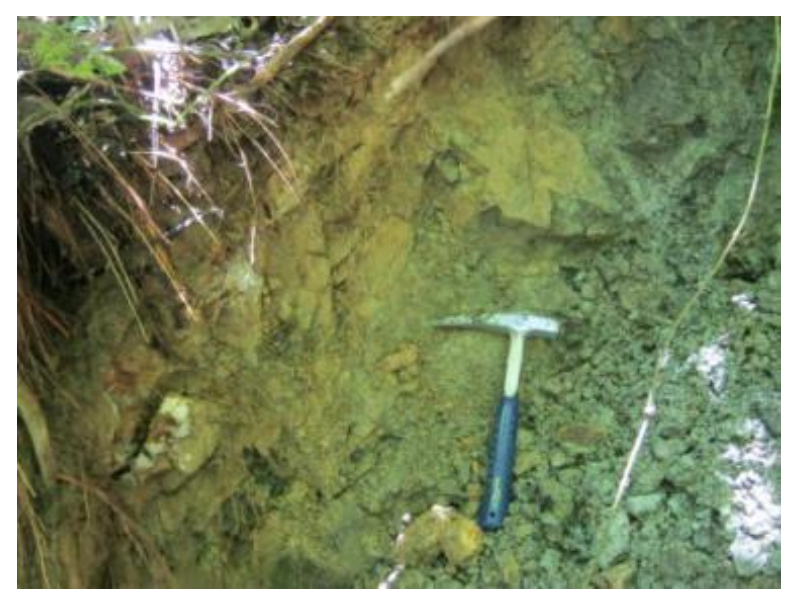

Gambar 6. Andesit yang mengalami alterasi argilik di Sungai Polangkok Besar.

\section{Alterasi propilitik}

Zona alterasi ini dijumpai pada satuan lava andesit yang berada di sekitar urat serta di sekitar retas-retas diorit. Ciri dari zona alterasi ini adalah kehadiran klorit yang menggantikan mineral primer seperti biotit dan piroksen. Pada beberapa tempat dijumpai alterasi propilitik yang cukup intensif yang ditandai dengan kehadiran klorit yang melimpah dan batuan yang berubah warna menjadi hijau keputihan (Gambar 7).

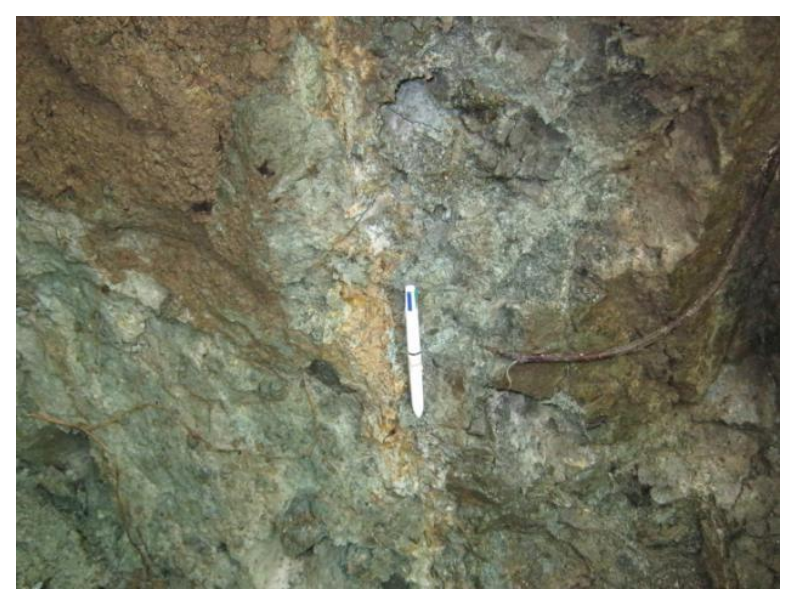

Gambar 7. Andesit yang mengalami alterasi propilitik di Sungai Polangkok Kecil.

\section{Mineralisasi dan Penyebaran Bongkah Urat}

Penyebaran urat kuarsa pada daerah penelitian umumnya sulit untuk didelineasi karena umumnya dijumpai sebagai bongkah urat kuasa pada alur sungai maupun pada lereng. Bongkah urat kuarsa pada sungai Polangkok Besar menunjukkan kehadiran mineralisasi yang menarik, yang ditandai oleh kehadiran pirit, sedikit kalkopirit, dan mineral sulfida halus bertekstur banding. Berdasarkan pengamatan megaskopis dari sampel batuan dan singkapan, pada daerah penelitian tidak dijumpai adanya kehadiran butiran emas secara langsung di dalam batuan, akan tetapi indikasi yang menarik ditunjukkan oleh kehadiran mineralisasi pada urat kuarsa di daerah penelitian. Singkapan urat kuarsa hanya dijumpai pada daerah Sungai Polangkok Besar yaitu sebanyak dua urat kuarsa. Urat kuarsa tersebut umumnya membentuk suatu zona yang terdiri atas beberapa urat kecil yang memiliki orientasi sama. Berdasarkan ciricirinya, urat kuarsa tersebut merupakan endapan epitermal sulfidasi rendah [29-31]. 
Urat P1 ditemukan di hulu cabang kiri Sungai Polangkok Besar yaitu pada lokasi pengamatan A01. Urat P1 tersebut berarah relatif barat laut-tenggara $\left(\mathrm{N} 160^{\circ} \mathrm{E} / 40^{\circ}\right)$ dengan lebar sekitar 3 meter (Gambar 8A). Urat P1 merupakan suatu zona urat yang tersusun oleh beberapa urat kecil yang berorientasi sama. Pada urat ini dijumpai mineralisasi yang cukup melimpah berupa pirit dan kehadiran jalur-jalur sulfida yang melimpah dengan ketebalan 2-5 mm (Gambar 8B).
Urat P2 dijumpai pada cabang kanan Sungai Polangkok Besar yaitu pada lokasi pengamatan B01. Urat ini memiliki orientasi relatif barat laut-tenggara $\left(\mathrm{N} 335^{\circ} \mathrm{E} / 57^{\circ}\right)$ dengan lebar sekitar 3 meter (Gambar 9A). Mineralisasi cukup melimpah dengan kehadiran pirit berukuran sedang sampai halus pada rekahan-rekahan halus dalam urat (Gambar 9B).
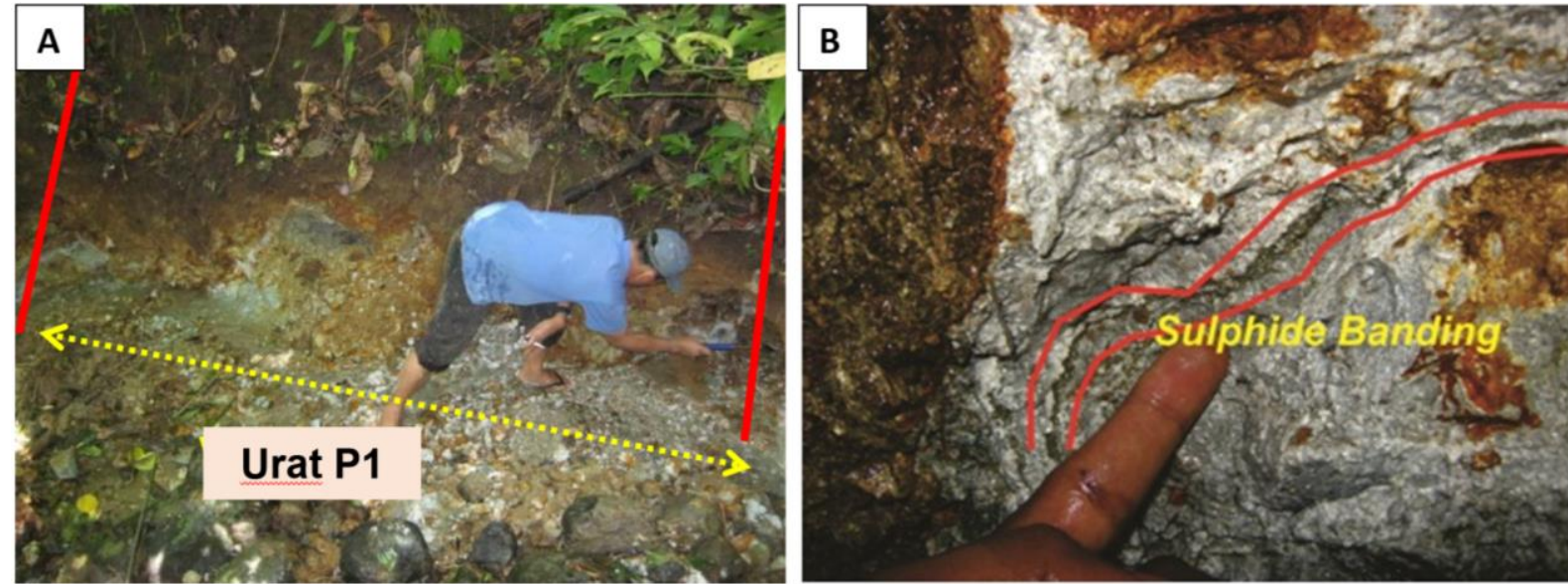

Gambar 8. (a) Singkapan urat P1 di cabang kiri Sungai Polangkok Besar, dan (b) kenampakan closed-up dari sulphide banding pada urat $\mathrm{P} 1$ tersebut.
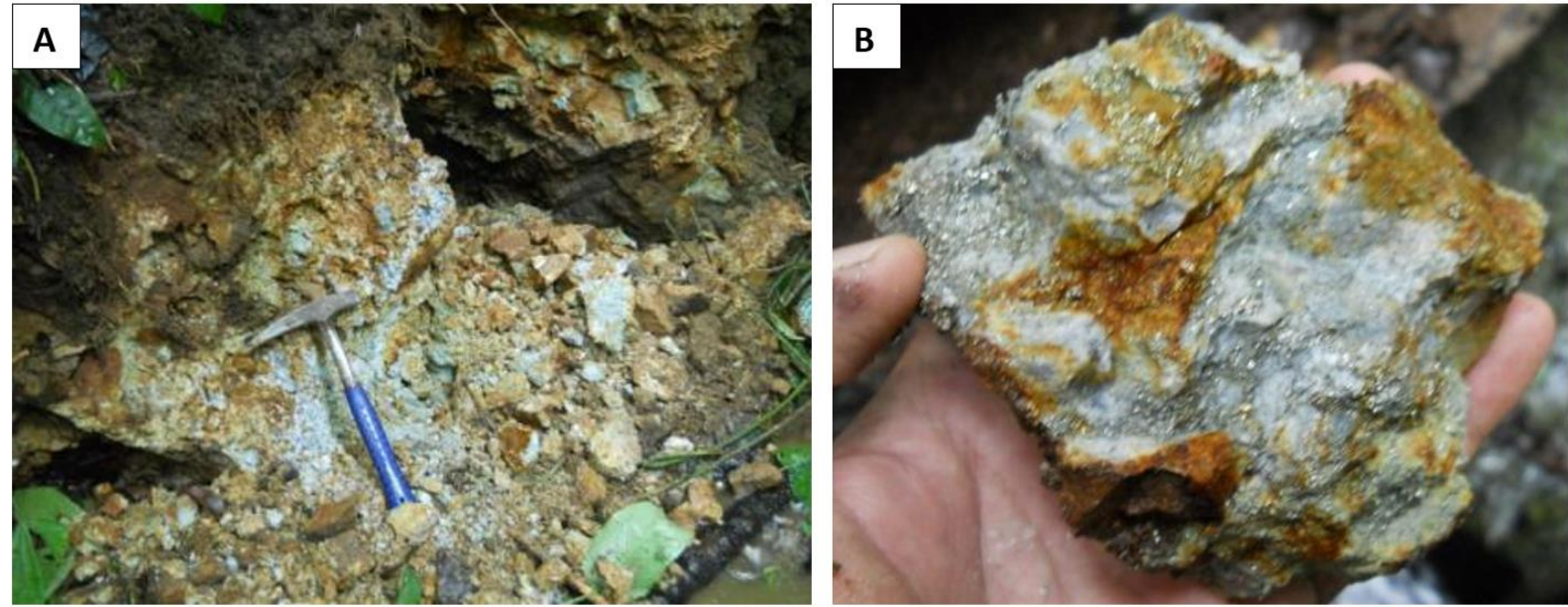

Gambar 9. (a) Singkapan urat P2 pada cabang kanan Sungai Polangkok Besar, dan (b) mineralisasi pada urat P2 dengan pirit yang melimpah. 


\section{Litogeokimia}

\section{Geokimia Batuan}

Sebanyak 29 sampel batuan dianalisis untuk mendapatkan informasi mengenai kadar unsur logam bernilai ekonomis seperti $\mathrm{Au}, \mathrm{Cu}$, $\mathrm{Pb}, \mathrm{Zn}, \mathrm{Ag}$, dan As dalam batuan (Tabel 1).
Kadar unsur-unsur tersebut menunjukkan indikasi yang cukup menarik yaitu semua unsur berada di atas nilai ambang batas bawah atau lower detection limit (DL). Sebaran kadar unsur $\mathrm{Au}, \mathrm{Ag}$, dan $\mathrm{Cu}$ pada daerah penelitian, dapat dilihat pada Gambar 10.

Tabel 1. Hasil analisis geokimia sampel batuan.

\begin{tabular}{|c|c|c|c|c|c|c|}
\hline Unsur & Au & $\mathbf{C u}$ & $\mathbf{P b}$ & $\mathbf{Z n}$ & Ag & As \\
\hline Satuan & ppm & ppm & ppm & ppm & ppm & ppm \\
\hline DL & 0,005 & 2 & 4 & 2 & 1 & 40 \\
\hline Metode Analisis & FA50 & GA02 & GA02 & GA02 & GA02 & GA02 \\
\hline $\mathrm{A} / \mathrm{RS} / 01 \mathrm{~A}$ & 0,093 & 6 & 9 & 78 & 2 & $<40$ \\
\hline $\mathrm{A} / \mathrm{RS} / 01 \mathrm{~B}$ & 0,111 & 10 & 6 & 81 & 2 & 60 \\
\hline $\mathrm{A} / \mathrm{RS} / 01 \mathrm{C}$ & 0,089 & 6 & 6 & 85 & $<1$ & $<40$ \\
\hline $\mathrm{A} / \mathrm{RS} / 01 \mathrm{D}$ & 0,142 & 10 & 36 & 90 & 3 & $<40$ \\
\hline $\mathrm{A} / \mathrm{RS} / 01 \mathrm{E}$ & 0,239 & 7 & 21 & 24 & 4 & $<40$ \\
\hline $\mathrm{A} / \mathrm{RS} / 01 \mathrm{~F}$ & 0,075 & 4 & 12 & 133 & $<1$ & $<40$ \\
\hline $\mathrm{A} / \mathrm{RS} / 01 \mathrm{G}$ & 0,137 & 24 & 11 & 92 & 3 & 70 \\
\hline $\mathrm{A} / \mathrm{RS} / 01 \mathrm{H}$ & 0,227 & 16 & 46 & 50 & 3 & $<40$ \\
\hline $\mathrm{A} / \mathrm{RS} / 03$ & 0,024 & 10 & 27 & 777 & $<1$ & $<40$ \\
\hline A/RS/09 & 0,015 & 174 & 12 & 191 & 6 & 80 \\
\hline $\mathrm{A} / \mathrm{RS} / 10 \mathrm{~A}$ & 0,006 & 47 & 9 & 112 & $<1$ & $<40$ \\
\hline $\mathrm{A} / \mathrm{RS} / 10 \mathrm{~B}$ & 0,036 & 86 & 9 & 519 & $<1$ & $<40$ \\
\hline $\mathrm{A} / \mathrm{RS} / 12$ & 0,005 & 51 & 5 & 71 & $<1$ & $<40$ \\
\hline B/RS/01 & 0,161 & 478 & 7 & 59 & $<1$ & $<40$ \\
\hline $\mathrm{A} / \mathrm{RF} / 05$ & 0,033 & 565 & 12 & 71 & $<1$ & $<40$ \\
\hline $\mathrm{A} / \mathrm{RF} / 06$ & 0,019 & 7 & 32 & 117 & $<1$ & $<40$ \\
\hline $\mathrm{A} / \mathrm{RF} / 07$ & 0,039 & 22 & $<4$ & 51 & $<1$ & $<40$ \\
\hline $\mathrm{A} / \mathrm{RF} / 08$ & 0,169 & 22 & 387 & 14 & $<1$ & $<40$ \\
\hline A/RF/09 & 0,021 & 6 & 40 & 62 & $<1$ & $<40$ \\
\hline $\mathrm{A} / \mathrm{RF} / 13$ & 0,014 & 183 & 4 & 20 & $<1$ & $<40$ \\
\hline $\mathrm{A} / \mathrm{RF} / 14$ & 0,011 & 3 & 5 & 44 & $<1$ & $<40$ \\
\hline $\mathrm{A} / \mathrm{RF} / 15$ & 0,033 & 108 & 4 & 19 & $<1$ & $<40$ \\
\hline $\mathrm{A} / \mathrm{RF} / 19 \mathrm{~A}$ & 0,005 & 2 & 7 & 13 & $<1$ & $<40$ \\
\hline $\mathrm{A} / \mathrm{RF} / 19 \mathrm{~B}$ & 0,01 & 13 & 329 & 5 & 15 & $<40$ \\
\hline $\mathrm{B} / \mathrm{RF} / 10$ & 0,044 & 50 & 31 & 138 & $<1$ & 60 \\
\hline $\mathrm{B} / \mathrm{RF} / 11$ & 0,005 & 222 & 25 & 50 & $<1$ & $<40$ \\
\hline $\mathrm{B} / \mathrm{RF} / 16$ & 0,206 & 21 & 7 & 36 & $<1$ & $<40$ \\
\hline $\mathrm{A} / \mathrm{RS} / 01 \mathrm{C} 2$ & 0,312 & 8 & 24 & 67 & 4 & $<40$ \\
\hline A/RS/01E2 & 0,237 & 8 & 23 & 53 & 4 & $<40$ \\
\hline
\end{tabular}




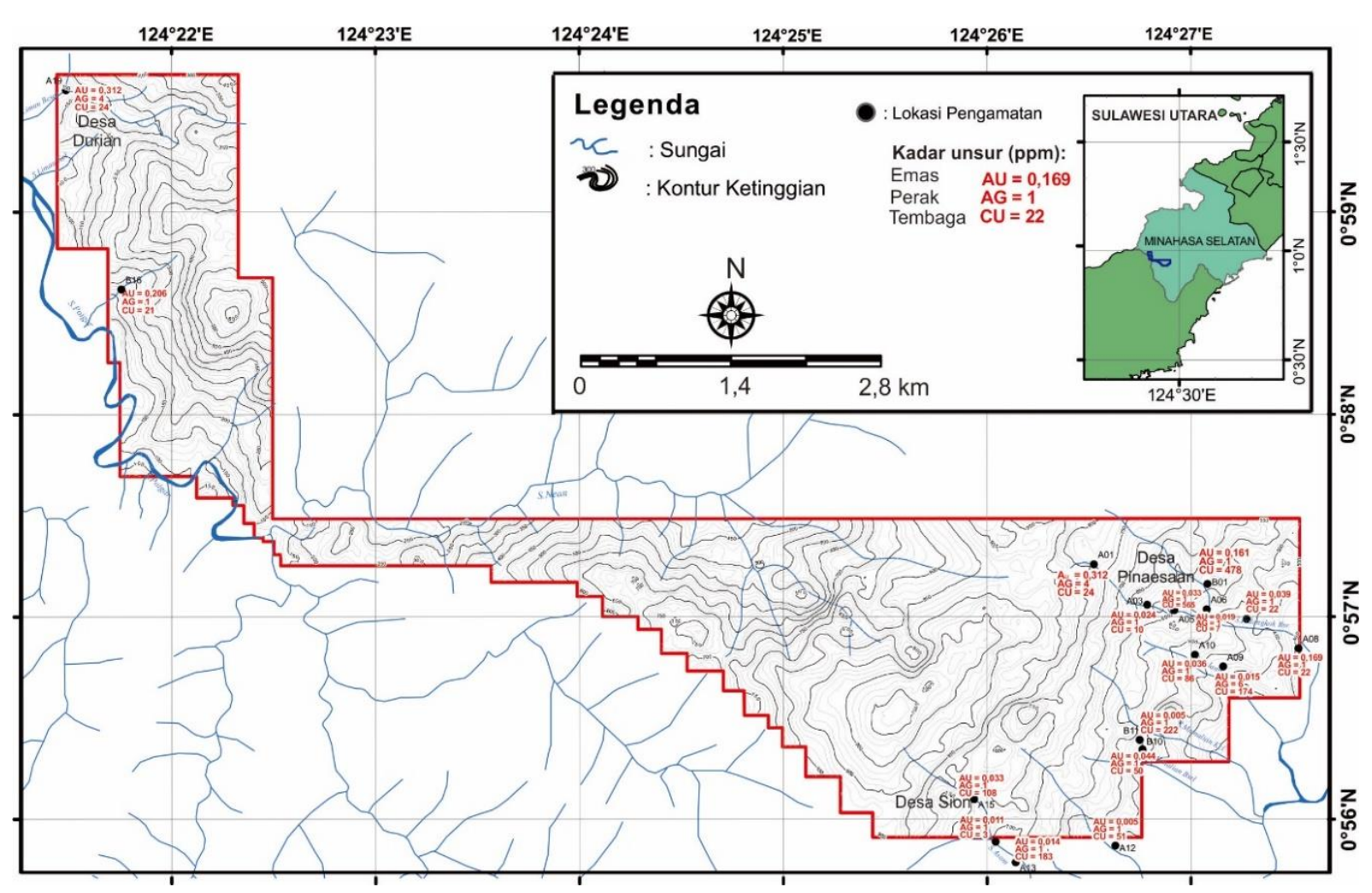

Gambar 10. Peta sebaran kadar Au, Ag dan $\mathrm{Cu}$ (dalam ppm) pada daerah penelitian.

\section{Geokimia Sedimen Sungai}

Sebanyak 16 sampel sedimen sungai (BLEG) dianalisis untuk mendapatkan informasi mengenai kehadiran zona-zona termineralisasi pada daerah penelitian. Hasil analisis sampel BLEG dapat dilihat pada Tabel
Hasil analisis geokimia tersebut menunjukkan rentang data yang cukup besar baik pada unsur $\mathrm{Au}$ maupun Ag. Analisis dan interpretasi data geokimia akan dijelaskan lebih rinci pada pembahasan selanjutnya. 2.

Tabel 2. Hasil analisis geokimia sampel BLEG.

\begin{tabular}{|c|c|c|c|c|c|}
\hline Unsur & $\mathbf{A u}$ & Ag & Unsur & Au & Ag \\
\hline Satuan & $\mathrm{ppb}$ & $\mathrm{ppb}$ & Satuan & $\mathrm{ppb}$ & $\mathrm{ppb}$ \\
\hline DL & 0,1 & 1 & DL & 0,1 & 1 \\
\hline $\begin{array}{l}\text { Metode } \\
\text { Analisis }\end{array}$ & $\mathrm{CNO}_{2}$ & $\mathrm{CNO}_{2}$ & $\begin{array}{l}\text { Metode } \\
\text { Analisis }\end{array}$ & $\mathrm{CNO}_{2}$ & $\mathrm{CNO}_{2}$ \\
\hline $\mathrm{B} / \mathrm{BL} / 02$ & 0,6 & 35 & $\mathrm{~B} / \mathrm{BL} / 14$ & 8,9 & 20 \\
\hline B/BL/04 & 4,6 & 47 & $\mathrm{~B} / \mathrm{BL} / 15$ & 17,9 & 27 \\
\hline B/BL/05 & 0,6 & 14 & B/BL/16 & 1,9 & 13 \\
\hline B/BL/06 & 8 & 70 & B/BL/17 & 0,2 & 2 \\
\hline B/BL/07 & 2,1 & 22 & $\mathrm{~A} / \mathrm{BL} / 02$ & 2,2 & 34 \\
\hline B/BL/09 & 1,1 & 19 & A/BL/04 & 6,6 & 22 \\
\hline $\mathrm{B} / \mathrm{BL} / 12$ & 0,7 & 15 & A/BL/09 & 7,3 & 71 \\
\hline $\mathrm{B} / \mathrm{BL} / 13$ & 2,9 & 25 & $\mathrm{~A} / \mathrm{BL} / 11$ & 1,9 & 19 \\
\hline
\end{tabular}




\section{PEMBAHASAN}

\section{Nilai Statistik Data Geokimia}

\section{Geokimia Batuan}

Nilai statistik data geokimia dari 29 sampel batuan yang dianalisis dapat dilihat pada Tabel 3. Sebagian besar kadar batuan yang dianalisis memiliki nilai Au di atas limit deteksi (detection limit), serta jauh lebih besar dibandingkan dengan kadar rata-rata unsur $\mathrm{Au}$ di kerak bumi yaitu 0,004 ppm [30], [31]. Hasil analisis statistik univariat (cf. [32], [33]), diperoleh nilai background sebesar 0,087 ppm Au dan nilai threshold sebesar 0,265 ppm Au. Nilai threshold menunjukkan bahwa hanya terdapat satu sampel yang memiliki kadar bernilai anomali yaitu pada sampel A/RS/01C2 (lokasi pengamatan A01) yang berada di hulu Sungai Polangkok Besar, sedangkan sampel lainnya berada di bawah nilai anomali. Berdasarkan data tersebut didapatkan bahwa anomali geokimia unsur $\mathrm{Au}$ dijumpai di daerah sepanjang Sungai Polangkok Besar, sekitar Desa Pinaesaan.

Nilai threshold penentuan anomali untuk unsur $\mathrm{Cu}$ adalah 349,43 ppm. Dari nilai tersebut diperoleh sebanyak dua sampel yang menunjukkan nilai kadar yang berada di atas nilai anomali yaitu pada sampel A/RS/05 (lokasi pengamatan A05) dan sampel B/RS/01 (lokasi pengamatan B01) yang berada pada alur Sungai Polangkok Besar, Desa Pinaesaan dengan kadar unsur tembaga $(\mathrm{Cu})$ masingmasing sebesar 565 ppm dan 478 ppm.

Hasil analisis untuk unsur $\mathrm{Pb}$ menunjukkan nilai threshold penentuan anomali sebesar 218,31 ppm. Dari nilai tersebut diperoleh sebanyak dua sampel yang menunjukkan nilai kadar berada di atas nilai anomali yaitu sampel $\mathrm{A} / \mathrm{RF} / 08$ yang diambil pada titik pengamatan A08 di daerah aliran sungai Polangkok Besar, Desa Pinaesaan dan sampel A/RF/19B yang diambil pada titik pengamatan A19 di daerah aliran Sungai Limau Besar, Desa Durian.

Nilai threshold penentuan anomali $\mathrm{Zn}$ pada sampel batuan adalah 426,16 ppm. Dari nilai tersebut diperoleh sebanyak dua sampel yang menunjukkan nilai kadar berada di atas nilai anomali yaitu sampel A/RS/03 yang diambil pada titik pengamatan A03 di daerah aliran Sungai Polangkok Besar dan sampel A/RS/10B yang diambil pada titik pengamatan A10 di daerah aliran Sungai Polangkok Kecil.

Sedangkan nilai threshold penentuan anomali untuk unsur Ag pada sampel batuan adalah 7,19 ppm. Dari nilai tersebut diperoleh hanya satu sampel yang menunjukkan nilai kadar berada di atas nilai anomali yaitu sampel $\mathrm{A} / \mathrm{RF} / 19 \mathrm{~B}$ yang diambil pada titik pengamatan A19 di daerah aliran Sungai Limau Besar, Desa Durian.

Tabel 3. Nilai statistik data geokimia batuan.

\begin{tabular}{lcccccc}
\hline $\begin{array}{l}\text { Unsur } \\
\text { Satuan }\end{array}$ & $\begin{array}{c}\mathbf{A u} \\
\mathbf{p p m}\end{array}$ & $\begin{array}{c}\mathbf{C u} \\
\mathbf{p p m}\end{array}$ & $\begin{array}{c}\mathbf{P b} \\
\mathbf{p p m}\end{array}$ & $\begin{array}{c}\mathbf{Z n} \\
\mathbf{p p m}\end{array}$ & $\begin{array}{c}\mathbf{A g} \\
\mathbf{p p m}\end{array}$ & $\begin{array}{c}\text { As } \\
\mathbf{p p m}\end{array}$ \\
\hline Kadar minimum & 0,005 & 2,00 & 4,00 & 5,00 & 1,00 & 40,00 \\
kadar maksimum & 0,312 & 565,00 & 387,00 & 777,00 & 15,00 & 80,00 \\
Mean & 0,087 & 74,79 & 39,66 & 107,66 & 2,24 & 43,79 \\
Median & 0,039 & 16,00 & 12,00 & 67,00 & 1,00 & 40,00 \\
Standar deviasi & 0,089 & 137,32 & 89,33 & 159,25 & 2,79 & 10,15 \\
Background & 0,087 & 74,79 & 39,66 & 107,66 & 2,24 & 43,79 \\
Threshold & 0,265 & 349,43 & 218,31 & 426,16 & 7,81 & 64,09 \\
\hline
\end{tabular}




\section{Geokimia Sedimen Sungai}

Nilai statistik data geokimia dari 16 sampel sedimen sungai (BLEG) yang dianalisis dapat dilihat pada Tabel 4. Sebaran kadar Au dan Ag serta nilai anomalinya dapat dilihat pada Gambar 11 dan Gambar 12. Nilai rata-rata kadar Au pada seluruh sampel BLEG adalah 4,21 ppm dengan simpangan baku sebesar 4,65 ppm. Seluruh sampel BLEG menunjukkan nilai kadar $\mathrm{Au}$ berada di atas nilai limit deteksi, sehingga data dianggap cukup representatif untuk menunjukkan adanya indikasi kehadiran daerah yang memiliki mineralisasi (cf. [32], [34]). Selisih antara nilai mean dan median tidak terlalu tinggi sehingga keduanya dapat dipakai untuk menentukan nilai background dan threshold. Untuk menyeragamkan analisis, nilai yang dipakai adalah nilai background dan threshold yaitu 4,22 ppb dan 13,52 ppb Au. Hanya satu sampel yang memiliki kadar $\mathrm{Au}$ di atas nilai threshold yaitu pada sampel B/BL/15 pada titik pengamatan B15 di aliran Sungai Asam, Desa Sion. Berdasarkan kehadiran titik anomali tersebut, dapat diinterpretasikan bahwa kemungkinan besar di aliran Sungai Asam di daerah Desa Sion memiliki zona mineralisasi yang menarik dan perlu ditindaklanjuti.

Nilai background dan threshold perak adalah 28,44 ppb dan 67,18 ppb. Terdapat dua titik sampel yang memiliki nilai kadar Ag anomali yaitu pada titik B06 yang berada di alur Sungai Polangkok Besar dan titik A09 yang berada di alur Sungai Polangkok Kecil. Kehadiran anomali unsur $\mathrm{Ag}$ tersebut menunjukkan bahwa di sekitar daerah aliran Sungai Polangkok Besar dan Polangkok Kecil terdapat indikasi keterdapatan zona mineralisasi yang perlu dilakukan eksplorasi lebih lanjut.

\section{Korelasi Data Geokimia}

Data sampel batuan, terutama sampel yang langsung diambil dari singkapan (rock sample/RS), menunjukkan bahwa nilai kadar unsur $\mathrm{Au}, \mathrm{Cu}, \mathrm{Pb}$, dan $\mathrm{Zn}$ relatif lebih besar dibandingkan dengan nilai limit deteksi, sedangkan untuk nilai kadar unsur Ag dan As umumnya lebih kecil dibandingkan dengan nilai ambang batas. Hal tersebut menunjukkan bahwa keempat unsur tersebut $(\mathrm{Au}, \mathrm{Cu}, \mathrm{Pb}$, dan $\mathrm{Zn}$ ) sangat mungkin terdapat sebagai mineral bijih seperti kalkopirit, galena, dan sfalerit, pada zona-zona mineralisasi daerah penelitian walaupun dalam kuantitas yang sangat kecil. Data sampel batuan menunjukkan beberapa sampel yang memiliki nilai anomali terutama untuk sampel yang diambil di aliran Sungai Polangkok Besar maupun Polangkok Kecil, Desa Pinaesaan.

Tabel 4. Nilai statistik data geokimia sedimen sungai (BLEG).

\begin{tabular}{lll}
\hline $\begin{array}{l}\text { Unsur } \\
\text { Satuan }\end{array}$ & $\begin{array}{l}\text { Au } \\
\text { ppm }\end{array}$ & $\begin{array}{l}\text { Ag } \\
\text { ppm }\end{array}$ \\
\hline Kadar minimum & 0,20 & 2,00 \\
kadar maksimum & 17,90 & 71,00 \\
Mean & 4,22 & 28,44 \\
Median & 2,15 & 22,00 \\
Standar deviasi & 4,65 & 19,37 \\
Background & 4,22 & 28,44 \\
Threshold & 13,52 & 67,18 \\
\hline
\end{tabular}

Sampel-sampel sedimen sungai (BLEG) menunjukkan kehadiran nilai anomali untuk unsur Au dan Ag pada lokasi yang berbeda. Kehadiran anomali tersebut merupakan indikasi bahwa daerah catchment sungai tempat diambilnya sampel tersebut memiliki zona batuan termineralisasi yang mengandung unsur-unsur logam seperti Au dan Ag (cf. [27], [35], [36]). 
Eksplorasi Geokimia untuk Menentukan Daerah Prospek Mineralisasi Emas Tipe Urat Epitermal: Studi Kasus di Daerah Tompaso, Kabupaten Minahasa Selatan, Sulawesi Utara Oleh: Arifudin Idrus, dkk.

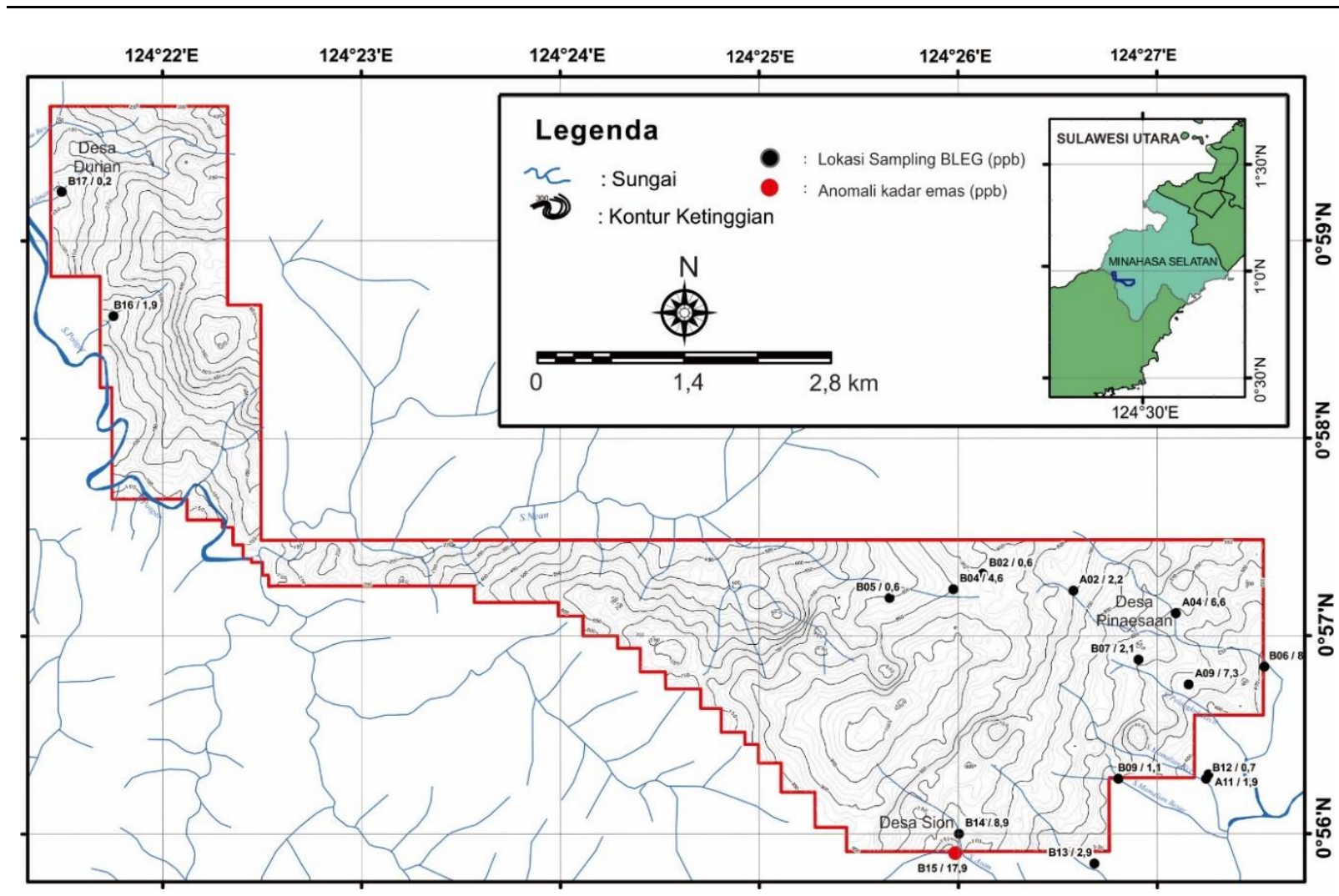

Gambar 11. Peta sebaran kadar emas (Au) dan nilai anomalinya.

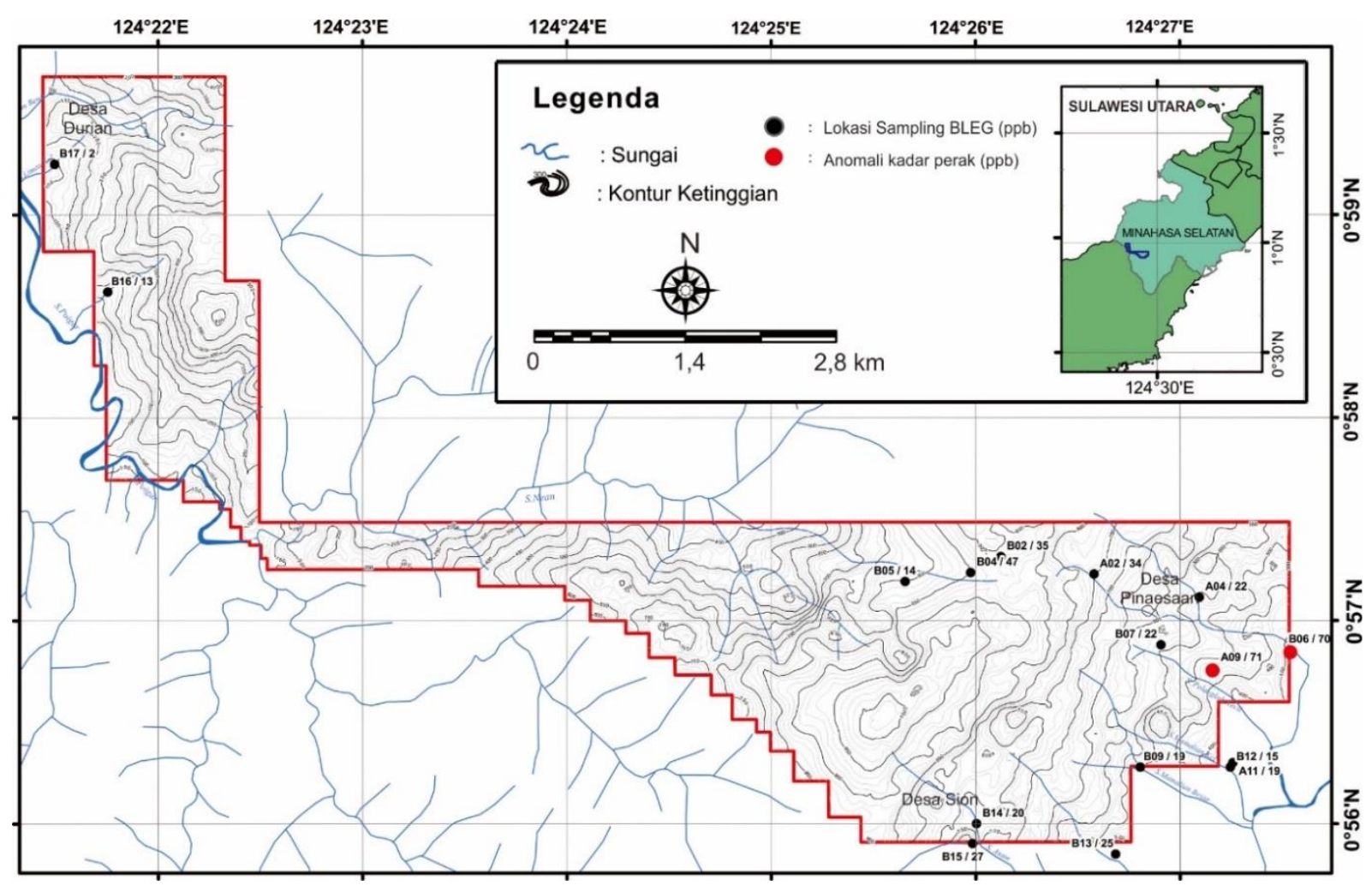

Gambar 12. Peta sebaran kadar perak (Ag) dan nilai anomalinya. 
Titik sampel yang mengandung kadar unsur $\mathrm{Au}$ bernilai anomali diperoleh pada sedimen sungai yang diambil di aliran Sungai Asam di Desa Sion, sedangkan untuk titik sampel bernilai anomali kadar unsur $\mathrm{Ag}$ dijumpai pada aliran Sungai Polangkok Besar dan Sungai Polangkok Kecil di Desa Pinaesaan. Penyebaran titik nilai anomali antara data geokimia batuan dengan data geokimia sedimen sungai (BLEG) tidak menunjukkan adanya korelasi positif terutama untuk unsur $\mathrm{Au}$, sedangkan pada unsur $\mathrm{Ag}$ menunjukkan korelasi positif dengan kehadiran batuan termineralisasi di daerah Polangkok Besar dan Polangkok Kecil.

\section{Interpretasi Daerah Prospek}

Berdasarkan hasil kegiatan eksplorasi tersebut, daerah target eksplorasi detail dapat dipersempit. Penentuan daerah prospek mengacu pada data fisik di lapangan, data penyebaran urat kuarsa, mineralisasi, zona alterasi yang dijumpai di lapangan, dan anomali, maka daerah penelitian dapat dibagi menjadi dua daerah prospek yaitu Prospek Polangkok dan Prospek Asam. Penentuan skala prioritas daerah prospek tersebut juga dikaitkan dengan kedetailan data serta tingkat keyakinan berdasarkan data geologi dan geokimia. Adapun rekomendasi daerah prospek untuk kegiatan berikutnya dapat dilihat pada Gambar 13.

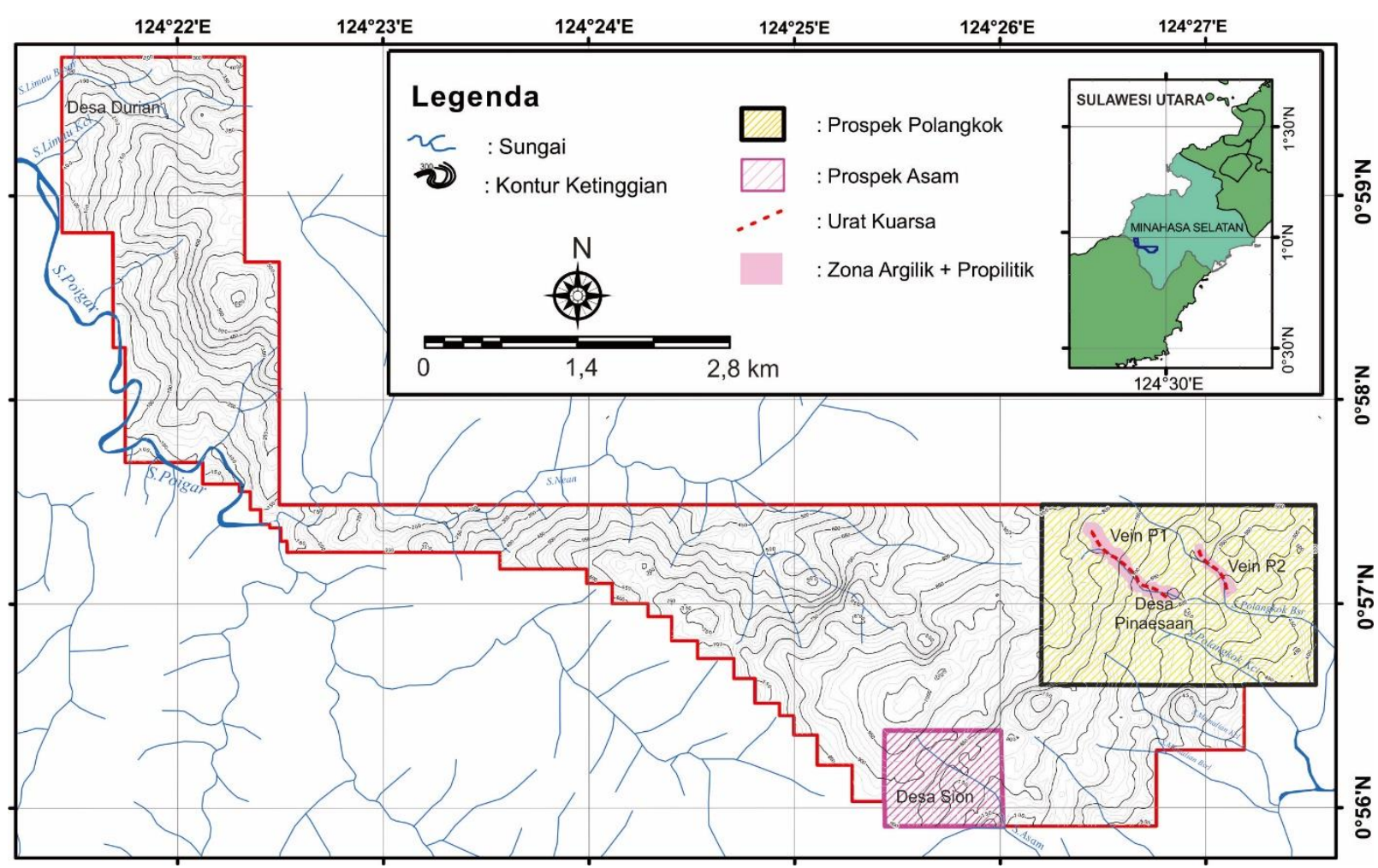

Gambar 13. Peta daerah prospek mineralisasi emas di daerah penelitian yang terdiri dari Prospek Polangkok dan Prospek Asam.

\section{Daerah Prospek Polangkok}

Daerah prospek ini berada di Desa Pinaesaan, yaitu pada sepanjang alur Sungai Polangkok Kecil dan Sungai Polangkok Besar (Gambar 13). Daerah ini tersusun atas satuan lava andesit dan intrusi diorit. Pada daerah hulu Sungai Polangkok Besar dijumpai 2 urat kuarsa (Urat P1 dan Urat P2) yang memotong lava andesit. Urat P1 ditemukan di hulu cabang kiri Sungai Polangkok Besar yaitu pada lokasi 
pengamatan A01. Urat P1 tersebut berarah relatif barat laut-tenggara $\left(\mathrm{N} 160^{\circ} \mathrm{E} / 40^{\circ}\right)$ dengan lebar sekitar 3 meter, sedangkan Urat P2 yang dijumpai pada cabang kanan Sungai Polangkok Besar yaitu pada lokasi pengamatan B01. Urat ini memiliki orientasi relatif barat laut-tenggara $\left(\mathrm{N} 335^{\circ} \mathrm{E} / 57^{\circ}\right)$ dengan lebar sekitar 3 meter. Berdasarkan hasil pengamatan lapangan, intensitas mineralisasi pada kedua urat P1 dan P2 tersebut cukup tinggi yang ditunjukkan oleh kehadiran mineral-mineral seperti pirit yang membentuk semacam lapisan sulfida (sulphide banding) searah dengan arah urat kuarsa. Urat P1 memiliki kadar Au antara 0,1-0,3 ppm, sedangkan Urat P2 memiliki kadar Au 0,161 ppm serta kadar unsur $\mathrm{Cu}$ yang cukup tinggi yaitu 475 ppm. Berdasarkan faktor geologi, geokimia, alterasi dan mineralisasinya, maka daerah Prospek Polangkok ini direkomendasikan sebagai daerah yang perlu ditindaklanjuti untuk eksplorasi lanjutan.

\section{Daerah Prospek Asam}

Daerah prospek ini terletak di sekitar aliran Sungai Asam di Desa Sion, Kecamatan Tompaso yang bersebelahan dengan Desa Pinaesaan. Pada daerah Prospek Asam ini tidak dijumpai singkapan batuan termineralisasi secara langsung, namun pada daerah ini terdapat beberapa sampel batuan yang memiliki indikasi kehadiran zona batuan termineralisasi seperti sampel $\mathrm{A} / \mathrm{RF} / 13$, $\mathrm{A} / \mathrm{RF} / 14$, dan $\mathrm{A} / \mathrm{RF} / 15$ dengan kadar di atas ambang batas yaitu 0,011-0,033 ppm. Ketiga sampel tersebut menunjukkan adanya alterasi lemah dan mineralisasi sulfida berupa pirit.

\section{KESIMPULAN DAN SARAN \\ Kesimpulan}

Litologi di daerah penelitian terdiri atas tiga satuan batuan yang merupakan bagian dari
Batuan Gunungapi Bilungala dan Intrusi Diorit Bone. Satuan litologi tersebut adalah lava andesit, breksi andesit yang diterobos oleh diorit. Alterasi hidrotermal pada batuan yang berkembang yaitu silica-clay, argilik, dan propilitik. Mineralisasi yang tinggi dijumpai pada satuan lava andesit, yaitu pada zona silica clay, dengan mineral berupa pirit dan sulfida halus. Penyebaran bongkah urat dengan mineralisasi tinggi terkonsentrasi di sepanjang alur Polangkok Besar. Urat kuarsa yang menunjukkan mineralisasi tinggi yaitu urat P1 dan Urat P2. Anomali unsur Au dan Ag pada sedimen sungai berada di sepanjang catchment Sungai Asam dan Sungai Polangkok Besar. Berdasarkan karakteristik alterasi, mineralisasi dan penyebaran urat, bongkah urat kuarsa dan batuan termineralisasi, serta anomali geokimia batuan maupun sedimen sungai maka daerah prospek yang direkomendasikan pada lokasi penelitian adalah Prospek Polangkok yang berada di sepanjang alur Sungai Polangkok Besar dan Polangkok Kecil di Desa Pinaesaan serta Prospek Asam pada hulu Sungai Asam di sekitar Desa Sion.

\section{Saran}

Hasil analisis data eksplorasi menunjukkan adanya indikasi mineralisasi yang signifikan pada daerah Prospek Polangkok. Oleh karena itu perlu dilakukan eksplorasi lanjutan untuk mendelineasi dan melokalisir zona urat yang ditemukan dengan metode geokimia tanah dan geofisika IP.

\section{UCAPAN TERIMA KASIH}

Tulisan ini merupakan bagian dari hasil pekerjaan jasa eksplorasi pada perusahaan, dengan tim eksplorasi dipimpin oleh penulis pertama. Kegiatan eksplorasi dibiayai oleh PT. Wahyu Perdana Binamulia. Penulis 
menyampaikan terimakasih kepada manajemen PT. Wahyu Perdana Binamulia (Bapak Soedjono Oesman) yang telah memberikan ijin untuk menggunakan data eksplorasi untuk dipublikasikan. Penulis juga menyampaikan terimakasih kepada para geologist dan helper yang telah membantu dalam pekerjaan lapangan. Masukan konstruktif dari reviewer sangat kami apresiasi dan terimakasih.

\section{DAFTAR PUSTAKA}

[1] J. C. Carlile dan A. H. G. Mitchell, "Magmatic Arcs and Associated Gold and Copper Mineralisation in Indonesia," dalam: T. M. van Leeuwen, J. W. Hedenquist, dan J. A. S. Dow, eds., Mineral Deposits of Indonesia, Discoveries of the Past 25 Years, Journal of Geochemical Exploration, vol. 50, hal. 91-142, 1994.

[2] R. H. Sillitoe, "Indonesian Mineral Deposit: Introductory Comments, Comparisons and Speculations," dalam: T. M. van Leeuwen, J. W. Hedenquist, dan J. A. S. Dow, Eds., Mineral Deposits of Indonesia: Discoveries of the Past 25 Years, Journal of Geochemical Exploration, vol. 50, hal. 1-11, 1994.

[3] A. Maryono, L. D. Setijadji, J. Arif, R. Harrison, dan E. Soeriatmadja, "Gold, Silver, and Copper Metallogeny of the Eastern Sunda Magmatic Arc Indonesia," Majalah Geologi Indonesia, vol. 29, hal. 85-99, 2014.

[4] J. C. Carlile, S. Digdowirogo, dan K. Darius, "Geological Setting, Characteristics and Regional Exploration for Gold in The Volcanic Arcs of North Sulawesi, Indonesia," dalam: J. W. Hedenquist, N. C. White, and G. Siddeley (Editors), Epithermal Gold Mineralization of the Circum-Pacific: Geology, Geochemistry, Origin and Exploration, Journal of Geochemical Exploration, vol. 35, hal. 105-140, 1990.

[5] I. Kavalieris, T. M. van Leeuwen, M. Wilson, "Geologic Setting and Styles of Mineralization, North Arm of Sulawesi, Indonesia," Journal of Southeast Asian Earth Sciences, vol. 7, hal. 113129, 1992.

[6] S. J. Turner, P. A. Flindell, D. Hendri, I. Hardjana, P. F. Lauricella, R. P Lindsay, B. Marpaung, dan G. P. White, "Sediment-hosted Gold Mineralization in the Ratatotok District, North Sulawesi, Indonesia," dalam: T. M. van Leeuwen, J. W. Hedenquist, dan J. A. S. Dow., eds., Mineral Deposits of Indonesia: Discoveries of the Past 25 Years, Journal of Geochemical Exploration, vol. 50, hal. 317-336, 1994.
[7] T. M. van Leeuwen dan P. E. Pieters, "Mineral Deposits of Sulawesi," Proceedings of the Sulawesi Mineral Resources of MGEI Annual Convention, Manado, hal. 1-19, 2011.

[8] A. Idrus, Sufriadin, dan I. Nur, "Hydrothermal Ore Mineralization in the Sulawesi: A View Point of Tectonic Setting and Metallogenesis," Proceedings of 36th HAGI and 40th IAGI Annual Convention and Exhibition, Makassar, hal. 298310, 2011.

[9] A. H. Hofstra dan O. D. Christensen, "Comparison of Carlin-type Deposits in the United States, China, and Indonesia: Implications for Genetic Models and Exploration," U.S. Geological Survey Open-File Report 02-131, 2002.

[10] M. A. Azzaman, A. Idrus, dan A. D. Titisari, "Geology, Hydrothermal Alteration and Mineralization of the Carlin-Type Gold Deposit at South Ratatotok, Southeast Minahasa Regency, North Sulawesi Province, Indonesia," International Conference on the Ocean and Earth Sciences, 18-20 November 2020, IOP Conferences Series (accepted), Lembaga Ilmu Pengetahuan Indonesia (LIPI), 2020.

[11] S. Shafieea dan E. Topal, "An overview of Global Gold Market and Gold Price Forecasting," Resources Policy, vol. 35, hal. 178-189, 2010.

[12] I. Yousef dan E. Shehadeh, "The Impact of COVID-19 on Gold Price Volatility," International Journal of Economics and Business Administration, vol. 8, hal. 353-364, 2020.

[13] J. A. Katili, "Past and Present Geotectonic Position of Sulawesi, Indonesia". Tectonophysics, vol. 45, hal. 289-322, 1978

[14] W. Hamilton, "Tectonics of the Indonesian region," U.S. Geological Survey, Professional Paper 1078, 1979.

[15] C. S. Hutchison, "Geological evolution of southeast Asia," Monographs on Geology and Geophysics, Oxford, 1989.

[16] R. Hall, "Cenozoic Geological and Plate Tectonic Evolution of SE Asia and the SW Pacific: Computer-based Reconstructions, Model and Animations," Journal of Asian Earth Sciences, vol. 20, hal. 353-431, 2002.

[17] B. Priadi, H. Bellon, R. C. Maury, M. Polvé, R. Soeria-Atmadja, dan J. C. Philippet, "Magmatic Evolution in Sulawesi in the Light of New ${ }^{40} \mathrm{~K}$ ${ }^{40}$ Ar Age Data," Proceedings of PIT IAGI XXIII, hal. 355-370, 1994.

[18] R. Sukamto, "The Structure of Sulawesi in the Light of Plate Tectonics," Proceedings of Regional Conference on the Geology and Mineral Resources of SE Asia, Jakarta, August 4-7, hal. 125, 1975.

[19] S. Garwin, R. Hall, dan Y. Watanabe, "Tectonic Setting, Geology, and Gold and Copper Mineralization in Cenozoic Magmatic Arcs of 
Southeast Asia and the West Pacific," Economic Geology 100 th Anniversary Volume, hal. 891-930, 2005.

[20] T. Apandi dan S. Bachri, Peta Geologi Regional Lembar Kotamobagu, Skala 1:250.000, Pusat Penelitian dan Pengembangan Geologi, Bandung, 1997.

[21] A. A. Levinson, Introduction to Exploration Geochemistry, John Wiley \& Sons, New York, 1973

[22] A. W. Rose, H. E. Hawks, dan J. H. Webb, Geochemistry in Mineral Exploration, Academic Press, New York, 1979.

[23] A. S. Joyce, Geochemical Exploration, The Australia Mineral Foundation Inc., Sydney, 1984

[24] M. Kusvart dan M. Bohmer, Prospecting and Exploration of Mineral Deposit, Elsevier, Amsterdam, 1986

[25] A. J. Eggo, Exploration Geochemistry, M. Sc Study Manual, James Cook University, Townsville, 1997.

[26] X. Xuejing dan W. Xueqiu, "Geochemical Exploration for Gold: a New Approach to an Old Problem," Journal of Geochemical Exploration, vol. 40, hal. 25-48, 1991.

[27] C. Kirkwood, P. Everett, A. Ferreira, dan B. Lister, "Stream Sediment Geochemistry as a Tool for Enhancing Geological Understanding: An Overview of New Data from South West England," Journal of Geochemical Exploration, vol. 163, hal. 28-40, 2016

[28] H. Yilmaz, D. R. Cohen, dan F. N. Sonmez, "Comparison Between the Effectiveness of Regional BLEG and -80\# Stream Sediment Geochemistry in Detection of Precious and Base Metal Mineral Deposits in Western Turkey," Journal of Geochemical Exploration, vol. 181, hal. 69-80, 2017.
[29] L. J. Buchanan, "Precious Metal Deposits Associated with Volcanic Environment in the Southwest Arizona," Geological Society Digest, vol. 14, hal. 237-262, 1981.

[30] L. Robb, Introduction to Ore-forming Processes, Wiley-Blackwell, Oxford, 2005.

[31] J. Ridley, Ore Deposit Geology, Cambridge University Press, Cambridge, 2013.

[32] E. J. M. Carranza, "Usefulness of Stream Order to Detect Stream Sediment Geochemical Anomalies," Geochemistry: Exploration, Environment, Analysis, vol. 4, hal. 341-352, 2004.

[33] P. N. Ranasinghe, G. W. A. R. Fernando, C. B. Dissanayake, M. S. Rupasinghe, dan D. L. Witter, "Statistical Evaluation of Stream Sediment Geochemistry in Interpreting the River Catchment of High-grade Metamorphic Terrains," Journal of Geochemical Exploration, vol. 103, hal. 97-114, 2009.

[34] T. Nuchanong, O. P. Lavin, dan I. Nichol, "Geochemical Dispersion of gold related to copper-gold mineralization in northeastern Thailand," Journal of Geochemical Exploration, vol. 40, hal. 49-71, 1991.

[35] P. K. Theobald, R. G. Eppinger, R. L. Turner, dan S. Shiquan, "The Effect of Scale on the Interpretation of Geochemical Anomalies," Journal of Geochemical Exploration, vol. 40, hal. 9-23, 1991.

[36] W. K. Fletcher, "Aspects of Exploration Geochemistry in Southeast Asia: Soils, Sediments and Potential for Anthropogenic Effects," Journal of Geochemical Exploration, vol. 57, hal. 31-43, 1996. 